\title{
Kadar Fenolik Total dan Flavonoid Total Seduhan Daun Tin (Ficus carica) Segar dan Kering dengan Air Mendidih
}

\author{
Oktavina Kartika Putri \\ D3 Farmasi \\ Akademi Farmasi Putra Indonesia Malang \\ E-mail: oktavina.chemistry@gmail.com
}

\begin{abstract}
Abstrak
Daun tin (Ficus carica) dikenal sebagai sumber antioksidan. Sifat antioksidan muncul karena adanya senyawa fenolik, flavonoid merupakan salah satu jenis senyawa fenolik. Masyarakat memanfaatkan daun tin dengan cara menyeduhnya dengan air mendidih sebagaimana teh. Penggunaan suhu yang tinggi dikhawatirkan merusak senyawa fenolik daun tin karena senyawa ini tidak tahan panas. Rusaknya senyawa fenolik akan menurunkan potensi antioksidan. Penelitian ini untuk mengetahui kadar fenolik total dan kadar flavonoid total seduhan daun tin segar dan kering dengan air mendidih. Metode Folin-Ciocalteu digunakan untuk penentuan kadar fenolik total sedangkan Metode Kolorimetri $\mathrm{AlCl}_{3}$ digunakan untuk penentuan kadar flavonoid total. Hasil yang diperoleh menunjukkan kadar fenolik total seduhan daun tin segar dan kering dengan air mendidih berturut-turut $0,0113 \pm 0,0004 \%$ dan $0,0076 \pm 0,0004 \%$ sedangkan kadar flavonoid total seduhan daun tin segar dan kering $0,0105 \pm 0,0003 \%$ dan $0,0025 \pm 0,0002 \%$. Dari hasil analisis data dengan Two Way Anova dapat disimpulkan bahwa penyiapan simplisia daun tin (segar dan kering) mempengaruhi kadar fenolik total dan kadar flavonoid total seduhan daun tin secara signifikan. Penggunaan air mendidih tidak menghilangkan kandungan senyawa fenolik dan flavonoid pada seduhan daun tin. Penyeduhan dengan air mendidih pada daun tin segar menghasilkan kadar fenolik total dan kadar flavonoid total tertinggi dibandingkan dengan daun tin kering.
\end{abstract}

Kata-kata kunci: kadar fenolik total, kadar flavonoid total, seduhan daun tin, daun tin segar, daun tin kering, air mendidih.

\begin{abstract}
Fig leaves (Ficus carica) are known as the source of antioxidants. Antioxidant properties arise caused by the presence of phenolic compounds, flavonoid is one of several types of phenolic compounds. Usually people takes advantage of fig leaves by brewing them with boiled water, like tea. The use of high temperature was feared to decompose the phenolic compounds of fig leaves because these compounds are not resistant to heat. Decomposing the phenolic compounds will decrease their antioxidant potential. This research was to determine the total phenolic content dan total flavonoid content of fresh dan dried fig leaves with boiled water. Folin-Ciocalteu Method was used to determine the total phenolic content dan $\mathrm{AlCl}_{3}$ Colorimetric Method was used to determine the total flavonoid content. Total phenolic content of fresh dan dried fig leaves brew with boiled water were $0.0113 \pm 0.0004 \%$ dan $0.0076 \pm 0.0004 \%$ respectively. Total flavonoid content of fresh dan dried fig leaves brew was $0.0105 \pm 0.0003 \%$ dan $0.0025 \pm 0,0002 \%$ respectively. From the data analysis results with Two Way Anova, it can be concluded that the preparation of fig (fresh dan dried) simplicia significantly affects the total phenolic content dan total flavonoid content. The use of boiling water did not eliminate the content of phenolic compounds dan flavonoids in fig leaves brew. Brewing with boiling water on fresh fig leaves produced the highest phenolic levels dan highest total flavonoid levels compared to the dried one.
\end{abstract}

Keywords: total phenolic content, total flavonoid content, tin leaf brew, fresh fig leaf, dried fig leaf, boiled water.

\section{PENDAHULUAN}

Akhir-akhir ini penggunaan antioksidan sangat populer di kalangan masyarakat karena dipercaya dapat melawan radikal bebas yang terdapat dalam tubuh, yang didapat dari hasil metabolisme tubuh, polusi udara, cemaran makanan, sinar matahari, dan sebagainya (Werdhasari, 2014). Radikal bebas adalah molekul yang pada orbit terluarnya mempunyai satu atau lebih elektron yang tidak berpasangan, sangat labil dan reaktif sehingga 
dapat menimbulkan kerusakan pada DNA, lipid, protein dan karbohidrat (Sari, 2016). Radikal bebas memiliki efek yang sangat buruk bagi kesehatan di antaranya dapat menyebabkan penuaan dini, kanker, aterosklerosis, (penyempitan pembuluh darah), penyakit gangguan hati, ginjal, katarak, reumatik, dan diabetes (Khaira, 2010). Beragam tumbuhan yang dapat ditemukan di sekitar kita memiliki potensi sebagai antioksidan seperti buah-buahan, umbi-umbian, rimpang, daun-daunan, dan lainlain.

Berdasarkan penelitian yang dilakukan Ayucitra et al., (2011), senyawa fenolik bahan alam yang didapatkan dari ekstrak tongkol jagung dan kulit petai berpotensi sebagai antioksidan alami minyak goreng kelapa sawit. Bahkan kedua ekstrak tersebut memiliki kemampuan menghambat proses oksidasi yang lebih baik dibandingkan dengan antioksidan sintetik. Hal tersebut menunjukkan bahwa antioksidan alami juga memiliki potensi yang tak kalah dibandingkan dengan antioksidan sintetik.

Tanaman lain yang berpotensi sebagai antioksidan adalah daun tin (Ficus carica). Ekstrak daun tin dengan beberapa pelarut memiliki potensi antioksidan yang sangat kuat ditandai dengan nilai $\mathrm{IC}_{50}<50 \mu \mathrm{g} / \mathrm{mL}$ (Agustina, 2017). Kadar senyawa fenolik yang tinggi menyebabkan tanaman tin memiliki kapasitas antioksidan yang tinggi (Solomon et al., 2006). Flavonoid merupakan salah satu golongan metabolit sekunder yang termasuk dalam kelompok besar senyawa fenolik (Zuraida et al., 2017). Hal ini sangat menarik untuk diteliti apakah tanaman yang memiliki kadar fenolik yang tinggi juga memiliki kadar flavonoid yang tinggi.

Penggunaan tanaman tin di Indonesia mulai marak, bahkan beberapa industri mulai mengemas daun tin kering dalam bentuk kantong teh celup. Untuk memanfaatkannya, masyarakat seringkali menggunakan air mendidih pada proses penyeduhan. Padahal, meningkatnya suhu dapat meningkatkan dekomposisi senyawa fenolik (Cheng et al., 2014). Dikhawatirkan dengan rusaknya senyawa fenolik (termasuk flavonoid) akan menurunkan potensi antioksidan yang dimilikinya.

Tujuan penelitian ini adalah untuk mengetahui kadar fenolik total dan flavonoid total seduhan daun tin segar dan kering dengan air mendidih. Berdasarkan penelitian yang dilakukan oleh Rababah et al., (2015), tumbuhan segar memiliki kadar fenolik total, flavonoid, dan aktivitas antioksidan yang lebih tinggi serta memiliki warna yang lebih baik daripada tumbuhan kering. Oleh karena itu, digunakan daun tin segar dan kering untuk dibandingkan kadar fenolik total dan flavonoid totalnya dengan penyeduhan menggunakan air mendidih. Diharapkan hasil penelitian yang diperoleh dapat memberikan informasi tentang penyiapan simplisia (segar atau kering) yang dapat memberikan kadar fenolik total dan flavonoid total yang lebih tinggi untuk mendapatkan manfaat antioksidan yang lebih baik.

\section{METODE}

\section{Alat dan Bahan}

Kadar fenolik total dan flavonoid total ditentukan dengan alat spektrofotometer UV-Vis (Hitachi U2900). Daun tin diperoleh dari Blimbing, Lowokwaru, Malang. Bahan-bahan yang digunakan antara lain akuades, $\mathrm{AlCl}_{3} 2 \%$, asam galat, kuersetin, metanol, $\mathrm{Na}_{2} \mathrm{CO}_{3} 7,5 \%$, dan reagen FolinCiocalteu 50\%.

\section{Penyeduhan Daun Tin Segar (Putri dan Wuryandari, 2018)}

Daun tin segar dicuci kemudian dikeringanginkan untuk menghilangkan air di permukaan daun. Setelah itu, daun tin dipotong-potong dengan lebar 2-3 mm kemudian diambil $\pm 6,25$ gram dan diseduh dengan $100 \mathrm{~mL}$ akuades mendidih. Seduhan ditutup hingga mencapai suhu ruangan kemudian disaring. Filtrat yang diperoleh digunakan untuk penentuan kadar fenolik total dan flavonoid total.

Penyeduhan Daun Tin Kering (Putri dan Wuryandari, 2018)

Sebanyak $\pm 6,25$ gram daun tin segar yang telah dipotong dikeringkan dengan suhu $25-30^{\circ} \mathrm{C}$ dengan oven hingga berbobot tetap. Kemudian daun tin kering yang diperoleh diseduh dengan $100 \mathrm{~mL}$ akuades mendidih. Seduhan ditutup hingga mencapai suhu ruangan kemudian disaring. Filtrat yang diperoleh digunakan untuk penentuan kadar fenolik total dan flavonoid total.

Penentuan Kadar Fenolik Total (Baba dan Malik, 2015; Wijayanti et al., 2017)

Penentuan kadar fenolik total dilakukan dengan Metode Folin-Ciocalteu dengan larutan standar asam galat. Tahap pertama adalah penentuan panjang gelombang maksimum larutan standar asam galat. Setelah diperoleh panjang gelombang maksimum, dibuat kurva standar asam galat. Tahap 
kedua adalah penyiapan sampel, seduhan daun tin ditambah dengan $0,5 \mathrm{~mL}$ metanol, $2,5 \mathrm{~mL}$ akuades, dan 2,5 mL pereaksi Folin-Ciocalteu $50 \%$ kemudian didiamkan selama 5 menit. Setelah itu, ditambahkan $2 \mathrm{~mL}$ larutan $\mathrm{Na}_{2} \mathrm{CO}_{3}$ 7,5\% lalu diinkubasi selama 15 menit pada suhu $45^{\circ} \mathrm{C}$. Setelah diinkubasi, sampel diukur absorbasinya pada panjang gelombang maksimum. Kadar fenolik total didapatkan dari hasil plotting absorbansi sampel ke persamaan kurva standar asam galat.

Penentuan Kadar Flavonoid Total (Wahdaningsih et al., 2017; Wijayanti dan Setiawan, 2017)

Penentuan kadar flavonoid total dilakukan dengan Metode Kolorimetri $\mathrm{AlCl}_{3}$ dengan larutan standar kuersetin. Tahap pertama adalah penentuan panjang gelombang maksimum larutan standar kuersetin. Setelah diperoleh panjang gelombang maksimum, dibuat kurva standar kuersetin. Tahap kedua adalah penyiapan sampel, seduhan daun tin ditambahkan metanol 4 mL kemudian ditambahkan $1 \mathrm{~mL}$ larutan $\mathrm{AlCl}_{3}$ $2 \%$. Kemudian, larutan diinkubasi pada suhu ruang selama 30 menit. Setelah diinkubasi, sampel diukur absorbasinya pada panjang gelombang maksimum. Kadar flavonoid total didapatkan dari hasil plotting absorbansi sampel ke persamaan kurva standar kuersetin.

\section{Analisis Data}

Analisis data dilakukan dengan uji Two Way Anova untuk mengetahui pengaruh penyiapan simplisia (segar dan kering) terhadap kadar fenolik total dan kadar flavonoid total seduhan daun tin.

\section{HASIL DAN PEMBAHASAN}

\section{Penentuan Kadar Fenolik Total}

Persamaan kurva standar asam galat yang didapatkan adalah y $=0,0956 \mathrm{x}+0,0029$ dengan nilai $\mathbf{R}^{2}=0,9986$. Kadar fenolik total didapatkan dari hasil plotting absorbansi sampel ke persamaan kurva standar asam galat. Nilai kadar fenolik total seduhan daun tin segar dan kering dengan air mendidih tersaji pada Gambar 1.

Penelitian terdahulu menunjukkan kadar fenolik total ekstrak daun tin yang didapatkan dari ekstraksi serbuk daun tin kering dengan air mendidih sebesar $1,43 \pm 0,006 \%$. Pengeringan dilakukan dengan oven bersuhu $60^{\circ} \mathrm{C}$ selama 24 jam. Jumlah serbuk yang diekstraksi $0,5 \mathrm{~g}$ dengan $5 \mathrm{~mL}$ air mendidih (Wahyuni dan Hertiani, 2016). Dibandingkan dengan hasil tersebut, kadar fenolik total seduhan daun tin segar dan kering dari penelitian ini jauh lebih rendah. Simplisia daun tin kering yang digunakan pada artikel yang telah disebutkan dihaluskan terlebih dahulu sebelum diseduh, sedangkan pada penelitian ini simplisia hanya dirajang. Perbedaan ukuran simplisia tersebut jelas mempengaruhi kadar fenolik total karena semakin kecil ukuran partikel simplisia maka semakin luas permukaannya sehingga mempercepat penetrasi pelarut ke dalam simplisia yang akan diekstrak (Tambun et al., 2016). Hasilnya, zat aktif yang terekstrak akan lebih tinggi.

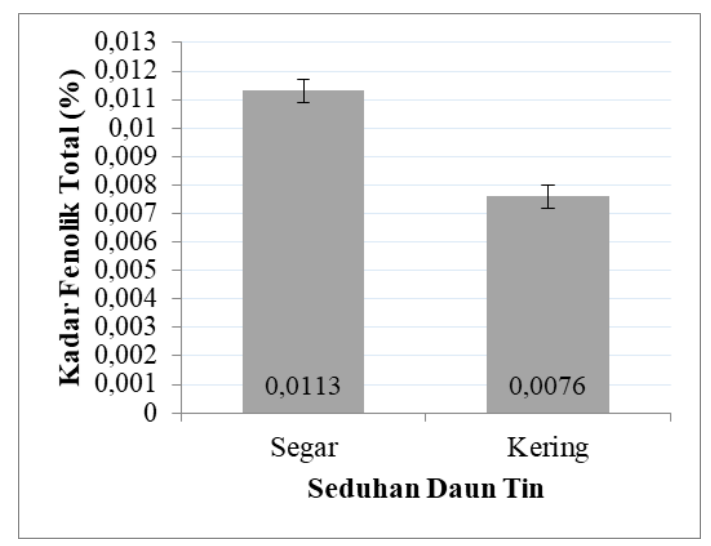

Gambar 1. Kadar Fenolik Total Seduhan Daun Tin

Selain metode ekstraksi, jenis pelarut (Sayuti, 2017), waktu dan suhu ekstraksi, serta ukuran partikel simplisia (Tambun et al., 2016), perbandingan simplisia-pelarut juga mempengarhi kadar zat aktif pada ekstrak. Pada artikel yang telah disebutkan, jumlah simplisia yang diekstraksi $0,5 \mathrm{~g}$ dengan $5 \mathrm{~mL}$ air mendidih (1:10) sedangkan pada penelitian ini $6,25 \mathrm{~g}$ dengan $100 \mathrm{~mL}$ air mendidih (1:16). Walaupun jumlah pelarut lebih banyak, kadar fenolik total pada penelitian ini tidak lebih tinggi. Hal ini terjadi karena penambahan pelarut yang lebih banyak melebihi titik optimum akan cenderung menurunkan kadar zat aktif dalam suatu ekstrak (Yulianingtyas dan Kusmartono, 2016).

Pada penelitian ini penggunaan air mendidih pada proses penyeduhan daun tin dilakukan untuk memperoleh kadar fenolik total yang tinggi. Kadar fenolik yang tertarik dari daun tin dipengaruhi oleh suhu. Pada padatan teh contohnya, suhu yang semakin tinggi akan memperlebar jarak antar molekul dalam padatan daun teh. Dengan semakin tinggi difusivitas pelarut air dan renggangnya 
molekul dalam padatan daun teh maka air akan lebih mudah untuk menembus padatan daun teh sehingga kafein yang terdapat dalam padatan daun teh terekstrak (Foust, 1990). Hal tersebut juga terjadi dalam daun tin.

Kadar fenolik total seduhan daun tin segar lebih tinggi dibandingkan dengan daun tin kering. Dibandingkan dengan proses pengeringan kering-angin, kadar fenolik total, aktivitas antioksidan, dan kandungan flavonoid pada tumbuhan menurun dengan digunakannya pengeringan oven (Rababah et al., 2015). Penggunaan suhu rendah $\left(25-30^{\circ} \mathrm{C}\right)$ pada pengeringan oven menyebabkan dibutuhkannya waktu yang lebih lama sampai diperoleh daun tin yang kering dan berbobot tetap. Pengeringan yang memakan waktu lama menyebabkan terjadinya penguraian senyawa fenolat oleh bantuan enzim fenolase yang terdapat dalam tumbuhan (Rivai et al., 2010) sehingga berakibat menurunnya kandungan senyawa fenolik pada seduhan daun tin kering.

Berdasarkan hasil analisis data dengan Two Way Anova dapat diketahui bahwa terdapat pengaruh secara signifikan penyiapan simplisia (segar dan kering) terhadap kadar fenolik total. Hal ini ditunjukkan dengan nilai sig. 0,000 (sig. $<0,005)$.

Penggunaan air mendidih pada proses penyeduhan tidak menghilangkan senyawa fenolik dalam daun tin segar maupun kering. Tetapi, perlu dilakukan penelitian lebih lanjut untuk mengetahui tren kadar fenolik total dengan variasi suhu untuk mengetahui suhu maksimum yang aman digunakan untuk menyeduh daun tin sehingga didapatkan khasiat optimum dari senyawa fenolik daun tin.

\section{Penentuan Kadar Flavonoid Total}

Persamaan kurva standar kuersetin yang didapatkan adalah $\mathrm{y}=0,079 \mathrm{x}-0,0063$ dengan nilai $\mathrm{R}^{2}=0,9986$. Kadar flavonoid total didapatkan dari hasil plotting absorbansi sampel ke persamaan kurva standar kuersetin. Nilai kadar flavonoid total seduhan daun tin segar dan kering dengan air mendidih tersaji pada Gambar 2.

Senyawa fenolik atau polifenol terdiri atas beberapa jenis senyawa antara lain flavonoid sederhana, asam fenolat, flavonoid kompleks, dan antosianin berwarna (Lin et al., 2016). Jadi, senyawa flavonoid merupakan bagian dari senyawa fenolik atau biasa disebut dengan senyawa polifenol karena flavonoid memiliki banyak gugus fenol di dalamnya. Tak heran jika kadar fenolik total dan flavonoid total yang didapatkan menunjukkan tren yang sama, baik kadarnya terhadap metode pengeringan simplisia maupun terhadap proses penyeduhan dengan air mendidih.

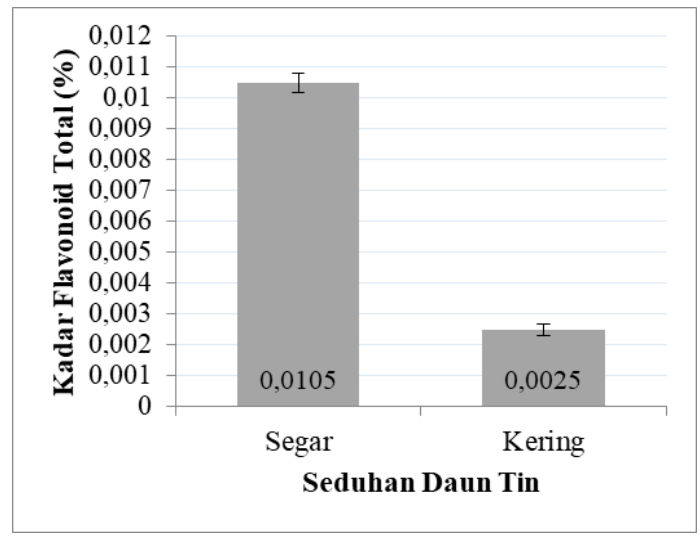

Gambar 2. Kadar Flavonoid Total Seduhan Daun Tin

Kadar fenolik total seduhan daun tin segar lebih tinggi dibandingkan dengan kadar flavonoid totalnya. Hal ini menunjukkan bahwa senyawa fenolik yang tertarik pada proses penyeduhan tidak hanya terdiri dari senyawa flavonoid, melainkan juga terdiri dari senyawa fenolik jenis lain yang perlu diteliti lebih lanjut dengan jumlah $\pm 0,0008 \%$ pada seduhan daun tin segar. Senyawa fenolik jenis lain (bukan flavonoid) yang terdapat dalam seduhan daun tin segar sebesar $\pm 0,0051 \%$.

Berdasarkan hasil analisis data dengan Two Way Anova dapat diketahui bahwa terdapat pengaruh secara signifikan penyiapan simplisia (segar dan kering) terhadap kadar flavonoid total. Hal ini ditunjukkan dengan nilai sig. 0,000 (sig. <0,005).

\section{KESIMPULAN}

Penyiapan simplisia daun tin (segar dan kering) mempengaruhi kadar fenolik total dan flavonoid total seduhan daun tin secara signifikan. Kadar fenolik total seduhan daun tin segar dan kering dengan air mendidih secara berturut-turut sebesar $0,0113 \pm 0,0004 \%$ dan $0,0076 \pm 0,0004 \%$ sedangkan kadar flavonoid total seduhan daun tin segar dan kering sebesar $0,0105 \pm 0,0003 \%$ dan $0,0025 \pm 0,0002 \%$. Penyeduhan dengan air mendidih pada daun tin segar menghasilkan kadar fenolik total dan kadar flavonoid total yang lebih tinggi dibandingkan dengan daun tin kering. Kadar fenolik total seduhan daun tin berbanding lurus dengan 
kadar flavonoid totalnya, jadi semakin tinggi kadar fenolik total seduhan daun tin maka semakin tinggi pula kadar flavonoid totalnya. Penggunaan air mendidih pada penyeduhan daun tin segar dan kering tidak menghilangkan keseluruhan senyawa fenolik pada umumnya dan flavonoid pada khususnya.

\section{UCAPAN TERIMAKASIH}

Terimakasih dan penghargaan yang setinggitingginya penulis sampaikan kepada Direktorat Riset dan Pengabdian Masyarakat - Direktorat Jenderal Penguatan Riset dan Pengembangan Kementrian Riset, Teknologi, dan Pendidikan Tinggi Republik Indonesia yang telah mendanai penelitian ini melalui skema Penelitian Dosen Pemula Tahun 2018.

\section{DAFTAR RUJUKAN}

Agustina, E., 2017. Uji Aktivitas Senyawa Antioksidan dari Ekstrak Daun Tin (Ficus carica Linn.) dengan Pelarut Air, Metanol dan Campuran Metanol-Air. KLOROFIL 1, 38-47.

Ayucitra, A., Indraswati, N., Mulyandasari, V., Dengi, Y.K., Francisco, G., Yudha, A., 2011. Potensi Senyawa Fenolik Bahan Alam sebagai Antioksidan Alami Minyak Goreng Nabati. WIDYA TEKNIK 10, 1-10.

Baba, S.A., Malik, S.A., 2015. Determination of total phenolic and flavonoid content, antimicrobial and antioxidant activity of a root extract of Arisaema jacquemontii Blume. Journal of Taibah University for Science 9, 449-454.

Cheng, Y., Xu, Q., Liu, J., Zhao, C., Xue, F., Zhao, Y., 2014. Decomposition of Five Phenolic Compounds in High Temperature Water. Journal of the Brazilian Chemical Society. https://doi.org/10.5935/01035053.20140201

Foust, S., 1990. Principles of Unit Operations, in: Principles of Unit Operations. John Wiley and Sons., Inc., New York.

Khaira, K., 2010. Menangkal Radikal Bebas dengan Anti-oksidan. Jurnal Sainstek 2, 183-187.

Lin, D., Xiao, M., Zhao, J., Li, Z., Xing, B., Li, X., Kong, M., Li, L., Zhang, Q., Liu, Y., Chen, H., Qin, W., Wu, H., Chen, S., 2016. An Overview of Plant Phenolic
Compounds and Their Importance in Human Nutrition and Management of Type 2 Diabetes. Molecules 21, 1374. https://doi.org/10.3390/molecules21101374

Putri, O.K., Wuryandari, W., 2018. Efek suhu penyeduhan daun tin (Ficus carica) segar dan kering terhadap kadar fenolik total. Jurnal Teknologi Pangan 12, 1-6.

Rababah, T.M., Al-u'datt, M., Alhamad, M., AlMahasneh, M., Ereifej, K., Andrade, J., Altarifi, B., Almajwal, A., Yang, W., 2015. Effects of drying process on total phenolics, antioxidant activity and flavonoid contents of common Mediterranean herbs. International Journal of Agricultural and Biological Engineering 8, 145-150.

Rivai, H., Nurdin, H., Suyani, H., Bakhtiar, A., 2010. Pengaruh Cara Pengeringan terhadap Perolehan Ekstraktif, Kadar Senyawa Fenolat dan Aktivitas Antioksidan dari Daun Dewa (Gynura pseudochina (L.) DC.). Majalah Obat Tradisional 15, 26-33.

Sari, A.N., 2016. Berbagai Tanaman Rempah sebagai Sumber Antioksidan Alami. Journal of Islamic Science and Technology 2, 203212.

Sayuti, M., 2017. Pengaruh Perbedaan Metode Ekstraksi, Bagian Dan Jenis Pelarut Terhadap Rendemen Dan Aktifitas Antioksidan Bambu Laut (Isis Hippuris). Technology Science and Engineering Journal 1, 166-174.

Solomon, A., Golubowicz, S., Yablowicz, Z., Grossman, S., Bergman, M., Gottlieb, H.E., Altman, A., Kerem, Z., Flaishman, M.A., 2006. Antioxidant Activities and Anthocyanin Content of Fresh Fruits of Common Fig (Ficus carica). Journal of Agricultural and Food Chemistry 54, 77177723. https://doi.org/10.1021/jf060497h

Tambun, R., Limbong, H.P., Pinem, C., Manurung, E., 2016. Pengaruh Ukuran Partikel, Waktu dan Suhu pada Ekstraksi Fenol dari Lengkuas Merah. Jurnal Teknik Kimia USU 5 .

Wahdaningsih, S., Wahyuono, S., Riyanto, S., Murwanti, R., 2017. Penetapan Kadar Fenolik Total dan Flavooid Total Ekstrak Metanol dan Fraksi Etil asetat Kulit Buah Naga Merah (Hylocereus polyrhizus (F.A.C.WEBER) Britton dan Rose). PHARMACON 6, 295-301.

Wahyuni, O.T., Hertiani, T., 2016. DPPH Radical Scavenging Activity, Total Phenolics and 
Flavonoids of Water Soluble Extracts Derived from Leaves and Fruit of Ficus carica L. and Ficus parietalis B1. Traditional Medicine Journal 21, 86-92. Werdhasari, A., 2014. Peran Antioksidan Bagi Kesehatan. Jurnal Biotek Medisiana Indonesia 3, 59-68.

Wijayanti, E.D., Setiawan, N.C.E.S., 2017. The effect of lactic acid fermentation on fig (Ficus carica) fruit flavonoid. Journal of Biological Researches 23, 40-44.

Wijayanti, E.D., Setiawan, N.C.E.S., Cristi, J.P., 2017. Effect of Lactic Acid Fermentation on Total Phenolic Content and Antioxidant Activity of Fig Fruit Juice (Ficus carica). Health Science International Conference Proceedings 282-289.

Yulianingtyas, A., Kusmartono, B., 2016. Optimasi Volume Pelarut dan Waktu Maserasi Pengambilan Flavonoid Daun Belimbing Wuluh (Averrhoa bilimbi L.). Jurnal Teknik Kimia 10, 58-64.

Zuraida, Z., Sulistiyani, S., Sajuthi, D., Suparto, I.H., 2017. FENOL, FLAVONOID, DAN AKTIVITAS ANTIOKSIDAN PADA EKSTRAK KULIT BATANG PULAI (Alstonia scholaris R.Br). Jurnal Penelitian Hasil Hutan 35, 211-219. https://doi.org/10.20886/jphh.2017.35.3. 211-219 